\title{
Günümüze Ulaşmayan Bir Osmanlı Sağlık Yapısı: Isparta / Hamidabad Gurebā Hastanesi
}

\author{
Nurcan YAZICI METIN*
}

\begin{abstract}
ÖZ
Osmanlı Devleti'nin son yüzyılında, sağlık hizmetlerinde modernleşmenin bir yansıması olarak sivil hastaneler inşa edilmeye başlanmıştır. İlk örneğini, 19.yüzyılın ortalarında İstanbul'da inşa edilen Bezmialem Vakıf Gurebâ Hastanesi'nin oluşturduğu bu sivil hastaneler, özelleşmiş bir tanımlamayla "gurebâ" hastanesi olarak isimlendirilmişlerdir. Tanzimat Dönemi ile başlayan gureba hastanelerinin inşası, özellikle Sultan II. Abdülhamid'in saltanatı döneminde Osmanlı coğrafyasının her tarafında, eyalet ve sancak merkezlerinde yaygınlaşmıştır. Padişahın ismine atfen "Hamidiye Gurebâ Hastanesi" olarak da tevsim edilen/isimlendirilen bu hastanelerin bir örneği de Konya Vilayeti'ne bağlı sancak olan Hamidabad /Isparta'da inşa edilmiştir.
\end{abstract}

Isparta Gurebâ Hastanesi'nin inşası, dönemin mutasarrıfı Hüseyin Hüsnü Bey’in girişimleriyle 1903 yılında başlatılmıştır. Resmi açılışı 1904 yılında, padişahın cülusuna denk gelen günde yapılan hastaneye, dönemin diğer yapı örneklerinde olduğu gibi padişahın ismi verilmiştir. Dönemin diğer gureba hastanelerinde olduğu gibi yardımlarla inşa edilen Isparta Gureba Hastanesinin daimi masrafları için de tahsisler yapılmıştır. Yaklaşık on yıl gibi bir süre hizmet veren hastane 1914 yılında yaşanan büyük depremde zarar görmüş ve yeniden yaptırılmak üzere yıktırılmıştır. Isparta'nın ilk hastanesi olan bu binanın yerine yeni bir hastanenin yapılması uzun yıllar almıştır.

Günümüze ulaşmayan ve yayınlarda hakkında çok sınırlı bilgi bulunan Isparta Gureba Hastanesi, Osmanlı Arşivi’nde bulunan 1903 tarihli keşif defteri ile ekindeki plân ve cephe çizimleri ve fotoğrafi

Prof. Dr. Mimar Sinan Güzel Sanatlar Üniversitesi, Fen Edebiyat Fakültesi, Sanat Tarihi Bölümü, İstanbul/Türkiye

E-posta: nurcan.metin@msgsu.edu.tr, ORCID: 0000 0003-3859-4847,

DOI: $10.32704 /$ erdem.2021.81.149

Makale Gönderim Tarihi: 30.03.2021 * Makale Kabul Tarihi: 29.11.2021 * (Araştırma Mk.) 
üzerinden incelenmiştir. İki katlı, neoklasik üsluptaki kargir yap1, orjinal plânında tanımlanan şekliyle "avlu” mekânına göre şekillenen dikdörtgen bir plân şemasına sahiptir. Mekânlar avlu olarak tanımlanan ve plânda dar kenarların orta alanında uzanan bu koridorun iki yanına yerleştirilmiştir. Dönemin diğer hastane örneklerinde görülen mekân dağılımı, burada da yer almaktadır. Kadın ve erkeklere mahsus koğuşlar, eczahane, doktor odası, muayene odası ve diğer hizmet mekânları avlu / koridor iki yanında yer almaktadır.

Isparta Gureba Hastanesi cephe düzeni ile dikkati çekmektedir. Neoklasik üsluptaki cephede, orjinal çiziminde "medhal" olarak tanımlanan girişin iki yanında, cepheyi aşan çokgen kesitli kulelere yer verilmiştir. Bu şekliye abidevi giriş düzeninin kullanıldığı yap1, aynı vilayet dahilinde Konya Vilayeti merkezinde, birkaç yıl önce, yüzyılın hemen başında tamamlanan sanayi mektebi ile çok benzer bir görünüm sunmaktadır. Gureba hastanesi binası, Konya Sanayi Mektebi'nin Birinci Ulusal Mimarlık üslubunun erken bir örneğini oluşturduğu, ayrıca bu üslupta başka yapı örneklerinin de olduğu bilinmekle birlikte Isparta Gureba Hastanesi, neoklasik üsluptaki kuleli giriş düzeniyle nadir uygulamalardan biridir. Bununla birlikte cephe köşelerine yerleştirilen kuleler dönem mimarlığında, farklı üsluplarda uygulanmıştır.

1903 tarihli keşif defteri ile çizimler üzerindeki isim ve mühürden hastanenin, "Mühendis Kalfaoğlu Yanko" tarafından tasarlandığ1 anlaşılmaktadır. Sancağın nafia mühendisi olan bu isim Isparta'da yeni baştan kargir olarak inşa edilen Kutlu Bey / Ulu Cami'nin de inşasını yürütmüştür. Mühendis Yanko'nun bu dönemde başka mimari eserlerde de çalışmış olması muhtemeldir. Isparta Gureba Hastanesi'nin tasarımcısının biliniyor olması dönemin gureba hastanelerinin kimler tarafından tasarlandığını örneklemesi açısından önemlidir.

Anahtar kelimeler: Osmanlı mimarisi, Batılılaşma, hastane, Gurebâ Hastanesi, Isparta Sancağı. 


\title{
The Ottoman Healt Building That Has Not Reached Today: Isparta / Hamidabad Gurebā Hospital
}

\begin{abstract}
In the last century of the Ottoman Empire, civil hospitals started to be constructed as a reflection of modernization in health services. These civil hospitals, while first example being Bezmialem Vakıf Gurebâ Hospital, which is built in Istanbul in mid-19th century, were named as "gurebâ" hospital with a specialized definition. The construction of gurebâ hospitals, starting with the Tanzimat Period, especially during the reign of Sultan Abdülhamid the Second, became widespread throughout the Ottoman geography, in the provincial and district centers. Another example for these hospitals, which were also called / named as "Hamidiye Gurebâ Hospital" in reference to the name of the Sultan, was built in Hamidabad / Isparta, which is a district of Konya Province.
\end{abstract}

The construction of Isparta Gurebâ Hospital was started in 1903 with the initiatives of Hüseyin Hüsnü Bey, the governor of the period. The hospital, which was officially opened in 1904, on the day corresponding to the sultan's enthronement, was given the name of the sultan just like in other building examples of the period. Allocations were made for the permanent expenses of the Isparta Gurebâ Hospital, which was built with assistance just like in the other hospitals of the period. The hospital, which served for about ten years, was damaged during the great earthquake in 1914 and was demolished to be rebuilt. It took many years for a new hospital to replace this building, which was the first hospital of Isparta.

Isparta Gurebâ Hospital, which has not reached today and has very limited information in publications, is examined through the construction book dated 1903 in the Ottoman Archive along with the plân and facade drawings and photographs in its annex. The twostory, neoclassical masonry building has a rectangular plan shaped according to the "courtyard" space as defined in its original plan. The spaces are placed on both sides of this corridor, which is defined as courtyard and extends in the middle of the narrow sides in the plan. The space distribution that was seen in other hospital examples of the period is also present here. Wards special for women and men, pharmacy, doctor's room, examination room and other service spaces are located on both sides of the courtyard / corridor.

Isparta Gurebâ Hospital attracts attention with its facade layout. On the facade with neoclassical style, on both sides of the entrance, which 
is defined as "medhal" in the original drawing, there are towers of polygonal cross section that extend beyond the facade. The building, in which the monumental entrance order is used in this form, offers a very similar look with the industrial school that was completed a few years ago, in the beginning of the century in the center of Konya Province within the same region. Although it is known that the building of the Gurebâ hospital is an early example of the First National Architecture style of Konya Industrial School and there are also other examples of buildings in this style, Isparta Gurebâ Hospital is one of the rare applications with its tower entrance layout in neoclassical style. However, the towers placed on the facade corners were used in different styles in period architecture.

It is understood from the discovery book dated 1903 and the name and seal on the drawings that the hospital was designed by "Engineer Kalfaoğlu Yanko". This person, who was the construction engineer of the district, also carried out the construction of Kutlu Bey / Ulu Mosque, which was built from the beginning as a masonry structure in Isparta. It is possible that Engineer Yanko worked on other architectural works during this period. The fact that the designer of Isparta Gurebâ Hospital being known is important in terms of exemplifying who designed the gurebâ hospitals of the period.

Keywords: Ottoman architecture, Westernization, hospital, Gurebâ Hospital, Isparta. 


\section{Giriş}

A ve Isparta olarak tanımlanan yerlesim Beyliği'ne ev sahipliği yapmış; I. Murad Döneminden (1362-1389) itibaren de Osmanlı hakimiyetine girmiştir. Bölgede kurulan Hamidoğulları Beyliğinin adına izafeten Anadolu Eyaletine bağlı Hamid Sancağı adını taşıyan Isparta, XIX.yüzyıldaki idari düzenlemelere paralel olarak Konya Vilayeti'ne bağlı Hamid/Hamidabad Sancağı olmuş; Osmanlı Dönemi yazışmalarında da çoğunlukla Hamidabad Sancağı olarak tanımlanmıştır (Böcüzade 2012: 23-32; Emecen 1999: 194-200).

Osmanlı'nın son döneminde Konya Vilayeti'ne bağlı Hamidabad Sancağı'nın merkezi olan Isparta, özellikle XIX.yüzyılın sonları ve XX.yüzyılın başlarında, mutasarrıfların etkin yönetimleri sayesinde kapsamlı imar faaliyetlerine sahne olmuştur. Isparta'daki hükümet konağı, daire-i askeriye, telgrafhane, hapishane, mekteb-i idadi gibi modern kamu binaları bu dönemde inşa edilmiştir (Böcüzade 2012: 257; Duymaz 2009: 218-226). XX.yüzyılın başlarında inşa edilen "Gureba Hastahanesi” de dönemin modern binaları arasindadir.

Osmanlı Devleti’nin son yüzyılında, sivil halka hizmet vermek amacıyla inşa edilmeye başlanan modern sağlık yapılarının örneklerinden olan gurebâ hastanesi, Isparta' da kimsesiz ve fakirlere hizmet verecek herhangi bir sağlik birimi olmadığı için yapılmıştır. Hastane binası günümüze ulaşmamıştır. $\mathrm{Bu}$ çalışmada, Osmanlı’nın modern hastane yapıları arasında yer alan Isparta / Hamidabad Gurebâ Hastanesi'nin, arşiv belgeleri ve orjinal görsel belgeler 1şı̆̆ında inşa süreci, mimarisi hakkında bilgi verilecek ve dönemi içindeki yeri değerlendirilecektir.

\section{Osmanlı’nın Modern Sağlık Yapıları: Gurebâ Hastaneleri:}

Osmanlı Devleti'nde sağlık hizmetlerinin yeniden düzenlenerek modern bir hale getirilmesi Tanzimat Dönemi ile başlamıştır. Bu döneme kadar darüşşifa, şifahane, darüssıhha gibi kurumlarda yürütülen sağlık hizmetlerindeki yeni düzenemeler, ilk olarak III. Selim döneminde, askeri alanda olmuştur (Cantay 2014: 7). Levent Çiftliği’ndeki kışlaya 1799 yılında, ilk modern hastane olan "Levent Çiftliği Hastahanesi" yaptırılmış; bunu başka askeri hastaneler takip etmiştir (Yavuz 1988: 124). Bu askeri hastanelerin, dönemin kışla mimarisini yansıtan örnekler olduğu anlaşılmaktadır (Pabuçcu 2014: 85-100). 
Sivil halka yönelik sağlık hizmetlerindeki modernleşmenin kurumsal yansıması ise gurebâ hastaneleridir. Garipler, kimsesizler anlamına gelen gurebâ kelimesi ile tanımlanan bu sivil hastanelerin ilk örneğini, 1847 senesinde İstanbul Yenibahçe'de, Sultan Abdülmecid'in annesi Bezmialem Valide Sultan vakfından inşa edilen Gurebâ-yı Müslimin Hastanesi oluşturmaktadır. Osmanlı'daki vakıf sistemi içinde değerlendirilebilecek bu modern sağlık kuruluşundan önce Edirnekapı Mihrimah Sultan Camii avlusundaki medresenin, kısa süreliğine de olsa gurebâ hastanesi olarak düzenlendiği bilinmektedir (Mursal 2017: 5). Bu anlamda tesis edilen ilk sivil hastanenin Osmanlı başkenti İstanbul'da, önce başka bir mekânın işlevlendirilmesiyle açıldığı; bu amaçla yeni baştan inşa edilen modern gurebâ hastanesinin ise Osmanlı'nın vakıf sisteminin devamı mahiyetinde, aynı yüzyılın ortalarında inşa edildiği anlaşılmaktadır (Yıldırım 2019: 201-241).

Özelleşmiş tanımlamayla, Osmanlı Döneminde "gurebâ hastahanesi” olarak isimlendirilen bu modern sağlık kurumları, Sultan Abdülmecid (1839-1861) Dönemi'nden başlayarak, Abdülaziz (1861-1876) ve daha yoğun olarak II. Abdülhamid dönemlerinde (1876-1909) inşa edilmişlerdir. Özellikle II. Abdülhamid Dönemindeki örnekler, gerek sultanın hayır eseri olarak gerekse cülûsu vesilesiyle sultana atfen inşa edilmesi ve sivil sağlık hizmetlerindeki modernleşmenin ivme kazandığı bir dönem olması sebebiyle sayıca fazladır. Sultanın döneminde inşa edilen veya açı1ışı yapılan birçok hastane de onun adına izafeten "Hamidiye Hastahanesi/Hamidiye Gurebâ Hastahanesi" olarak isimlendirilmiştir. Vilayet ve sancak merkezleri başta olmak üzere Osmanlı coğrafyasının hemen her tarafında inşa edilen bu hastaneler, gurebâ hastanesi isimlendirmesinin yanında, "Zükur ve İnas Hastahanesi" ya da frengi, veba gibi bulaşıcı hastalıklara yönelik olanları, bu isimlerle de adlandırılmıştır. "Gurebâ-yı Müslimin Hastahanesi” tanımı sık kullanılmakla birlikte bu hastanelerde, her milletten fakir ve kimsesiz hastalara ücretsiz sağllk hizmetinin verildiği bilinmektedir.

Gurebâ Hastaneleri, genellikle tek veya iki katlı kargir yapılardır. Bazı örnekleri günümüze gelebilen bu hastanelerin, farklı plân ve cephe kuruluşlarına sahip olduğu görülmektedir. Daha çok orta koridora açılan koğuş sisteminin kullanıldığı plân kuruluşlarına sahip olan bu hastane binalarında, dönemin birçok yapısının cephe kurgusunda görülen neoklasik üslubun yanında, fark1 cephe özelliklerinin yaygın olarak kullanıldığı anlaşılmaktadır. ${ }^{1}$

Örneğin Bolu Gurebâ Hastanesi neo-gotik bir cephe kuruluşuna sahiptir. Bk. Yazıcı Metin 2020a: 259. 


\section{Isparta/Hamidabad Gurebâ Hastanesi}

Kaynaklarda Hamidabad Sancağı'nın merkezi olan Isparta'daki ilk hastanenin, gurebâ hastanesi adıyla 1900 yılında mutasarrıf Hüsnü Bey tarafindan yaptırıldığ 1 yazmaktadır (Demirci 2009: 164). ${ }^{2} 1922$ yılında basılmış olan Türkiye'nin Sıhhi-i İçtimai Coğrafyası dizisinin Hamidabad (Isparta) Sanca$\breve{g} 1$ hakkındaki yayınında, o tarihte liva dahilinde bir hastane bulunmadığı belirtilmiş; daha önce "tesis ve küşad" olunan hastane binasının da H. 1330 (M. 1914) yılında meydana gelen depremde tamamen yıkıldığı ifade edilmiştir. Daha sonra şehir haricinde yeni baştan bir hastane binası inşasına başlanmış ve yarıya yakın kısmı tamamlanmış ise de kış mevsimi gelmesinden dolayı inşaata ara verilmiştir (Besim Zühdü 2013: 29). Yıkılan Gurebâ Hastanesi yerine yapılması planlanan 30 yataklı Memleket Hastanesi ancak 1922 yılında tamamlanabilmiştir (Demirci 2009: 164). ${ }^{3}$

Isparta'daki Gurebâ Hastanesi'ne, kentin son dönemi için önemli bir kaynak olan Böcüzade Tarihi'nde de yer verilmiştir. Burada "1318 ve 19 (1901-02) senelerinde depo-yu hümâyun garbına/batısına gelen Burdur-Dinar şoseleri üstünde istimlak edilen birkaç bahçeye" inşa edilmiş olan "gasılhane ve mutfak ve on iki oda ve bir salonu havi fevkâni ve tahtani otuz yataklık bir gurebâ hastahanesi” tanımlanmıştır. Mutasarrıf Hüsnü Bey zamanında yapılan hastanenin, mutasarrıfın buradan ayrılmasıyla ilgisiz kaldığ1, "hastanenin suyunun götürülmesine bile bakan olmamıştır" ifadelerinden anlaşılmaktadır (Böcüzade 2012: 257).

Böcüzade Tarihi'ni kendi notlarıyla özetleyerek yayınlayan torunu, Mutassrrıf Hakkı Behiç Bey (1914-1916) hakkında bilgi verip "depremin y1kamadıklarını yıkan mutasarrıf" tanımlamasıyla deprem sonrası Isparta'da yapılanları anlatırken, adı geçen mutasarrıfın depremde yıkılan hastanenin, eski yerinde ve eski temeller üzerinde yeniden yapılması için özel idare bütçesinden bir miktar para sağladığını, "vilayet emrini dinlemeyerek başka bir yerde hastane yapılmak üzere, eski hastane enkazını oraya buraya dağıttığını" yazmaktadır (Böcüzade Süleyman Sami 1983: 312, 319). ${ }^{4}$

Aynı bilginin tekrarlandığı bir diğer çalışmada, Gurebâ Hastanesi’nin şimdiki belediye binasının batısındaki Piri Efendi Mezarlığı'nın altındaki yerde yapıldığı da belirtilmiştir. Bakz. A. Şevki Duymaz 2009: 218.

3 Cumhuriyet Dönemi'nin hemen başında, vilayet merkezinde, idare-i hususiyeye ait 30 yataklı bir hastahane vardır. Bakz. Komisyon 2014: 2110.

4 Kuruluşundan Böcüzade'nin ölümüne kadar Isparta'nın tarihi, sosyal ve kültürel yapısının anlatıldığı iki ciltlik eser, torunu Suat Seren tarafından bugünkü harflere çevrilerek basılmış; bazı bölümlerine ilaveler yapılmış ve yorumlar, fotoğraflar eklenmiştir. Böcüzade Süleyman Sami, metne Nisan 1914 'te son halini vermeye başlamış ve 6 Mayıs 1915 tarihinde yazımını tamamlamıştır. Bakz: Böcüzade 2012: s. XXXII. 
Isparta/Hamidabad Sancağı'nda bir gurebâ hastanesinin inşa edilmesi sürecini Osmanlı Arşivi'nde bulunan yazışmalardan takip etmek mümkündür. 1903 yılında "görülen lüzum ve ihtiyaç" üzerine ve "merzânın/hastaların tedavisi için" sancak merkezinde bir hastane inşasına karar verilmiştir. Hastanenin ekli çizimlerinin yer aldığı keşif defteri, "Hamidabad Nafia Mühendisi" tarafından 12 Kasım 1903 tarihinde hazırlanmıştır (BOA., DH.MKT., 816/54, 30 Teşrin-i evvel 319, 12 Kasım 1903). Hastane için ahalinin ne miktarda yardımda bulunacağının isim ve miktar olarak tespit edilip gönderilmesi istenmiştir. Hastanenin inşa masraflarının nasıl karşılanacağının, iane defterinin sorulması üzerine, H. 2 Zilkade 1321/ M.19 Ocak 1904 tarihli yazışmada, "mukaddema inşasına başlanmış olunan hastahanenin", Hazine-i Celileye ve ahaliye yük olunmaksızın, "himmet sahibi ahalinin ianatıyla" inşa edileceği belirtilmiştir (BOA., DH.MKT., 816/54). Isparta'daki Gurebâ Hastanesi'nin, 1903 y1l sonunda, yardımsever halktan toplanan paralarla inşaatına başlandığı anlaşılmaktadır.

"Merzânın tedavisi için Hamidabad Sancağı merkezinde bir hastahane inşa olunmak üzere" mahalli belediye dairesi adına bir arsa satın alınmıştır. Arsadan bedel-i öşr alınmaması istenmiştir (BOA., İ.DFE., 15/41, 23 Teşrinisani 1320, 6 Aralık 1904). Hastane inşası için belediye adına satın alınan ve içerisinde ağaçlar bulunan bahçede, "biçare ve bivâye olup hasta olacak birtakım gurebâ ve emsalinin tedavisiyle muhafaza-i sıhhatlarini” sağlamak ve "de'avat-1 hayriye-i hazreti padişahi isticlal olunmak maksadıyla inşa olunan mezkur hastahane ebniyesi” için Konya valisi tarafından öşür vergisinin affı yolunda yazışmalar yapılmışıtır (BOA., ŞD, 1758/3, 8 Cemaziyelahir 1322, 20 Ağustos 1904). Belediye adına alınan bahçenin arazi-yi emiriyeden olması üzerine bu gibi yerlerde "gerek tarla, gerek bağ ve bahçe üzerine müceddeden ebniye inşası ve tayin ve takdir olunacak bedel-i öşrünün affi” padişahın emrine tabidir ve bu yolda istenen izin, satın alınan bu bahçenin/arsanın bedel-i öşürden/arazi-i öşrden istisnasına izin verilmiştir (BOA., DH.MKT., 886/4, 23 Cemazeyilahir 1322, 4 Eylül 1904).

Hastanenin inşaatının 1904 yılı sonuna doğru hızla bitirildiği anlaşılmaktadır. Aç1lış1, dönemin padişahı Sultan II. Abdülhamid'in 29. cülusuna, yani 1904 yılı 1 Eylül gününe, yetiştirilmeye çalışılmıştır. Hastanenin 1904 yılı sonunda resmi açılışı yapılabilecektir. "Yevm-i firuzede resm-i küşâdının icrâsı mukarrer olan" hastanenin, padişahın adıyla isimlendirilebilmesi için müsade istenmiştir (BOA., İ.HUS., 122/35, 14 Şaban 1322, 24 Ekim 1904). Cülus gününde resmi açılışının yapılması planlanan hastaneye, padişaha iza- 
feten "Hamidiye Hastahanesi" adı verilmiştir (BOA., BEO., 2436/182664, 15 Şaban 1322, 25 Ekim 1904). ${ }^{5}$

Cülus günü açılışı kararlaştırılan hastanenin bir fotoğrafı, liva mutasarrrıfı tarafindan gönderilmiş ve padişaha takdim edilmiştir. Buna istinaden adı geçen mutasarrıfin hizmet ve gayretleri takdirle karşılanmış, "nişan-1 zişan ile taltifi" uygun bulunmuştur (BOA., BEO., 2427/181978, 1 Şaban 1322, 11 Ekim 1904).

Hastanenin, ayrı olarak inşa edildiği anlaşılan mutfak, çamaşırhane, gasılhane ve eczanesinin açılışı ise 1905 yılı başında yapılmış ve bu vesile ile açı1ışta padişaha dua edilmiştir (BOA., DH.MKT., 997/29, 12 Safer 1323, 18 Nisan 1905). Sultanın 1904 yılındaki cülus gününe yetiştirilmeye çalışılan hastane binasının eksiklerinin daha sonra tamamlandığı anlaşılmaktadır.

Dönemin padişahı Sultan II. Abdülhamid'in adının verildiği Isparta'daki "Hamidiye Gurebâ Hastahanesi" daimi masraflarına karşılık olmak üzere "Aksu iskelesine indirilecek kerestelerden alınacak arziye resminin" tahsisi istenmiştir. Buraya indirilecek kereste Isparta ormanlarının mahsulü olduğundan, yeni kurulmuş olan hastanenin daimi masrafları için "Isparta kereste tacirlerinin Isparta ormanlarından kat' ettirecekleri kerestenin beher metro mik'abından yirmi paranın iâneten itası" uygun görülmüştür (BOA., Y.A.RES., 132/87, 20 Recep 1323, 20 Eylül 1905).

Hastane, dönemin yazışmalarında bir dönem, "Hamidabad sancağı merkezindeki Hamidiye Gurebâ Hastahanesi” olarak geçmektedir. Bununla birlikte 1907 senesinde alınan bir cihaz vesilesiyle hastanenin adı "Gurebâ-y1 Müslimin Hastahanesi” şeklinde tanımlanmıştır (BOA., Y.A.RES., 144/33, 19 Muharrem 1325, 4 Mart 1907). Bu tarihte, "Isparta Gurebâ-y1 Müslimin Hastahanesi namına Marsilya'dan İzmir'e" gelen "bir adet ufak kutuda cihaz-1 elektriğin imrarı”, yani gümrükten geçirilmesi istenmiştir. Bu yıllarda hastanenin teknik ihtiyaçları karşılanmaya çalışılmaktadır. Hastanenin sonraki y1llarda faaliyetini sürdürdüğü anlaşılmaktadır. 1909'da, "Isparta Sancağı Gurebâ Hastahanesi eczacılığına" Samuel Efendi vekaleten tayin edilmiştir (BOA., DH.MUI., 4/6, 20 Şaban 1327, 6 Eylül 1909).

Isparta Gurebâ Hastanesi, 1905 senesi yazışmalarında, frengi hastanesi olarak da isimlendirilmiştir. Bu tarihte, "frengi iletinin meni" için Isparta san-

Özellikle Sultan II. Abdülhamid Dönemi’nde, cülus gününe denk gelen tarihlerde temel atma ve açılış törenlerinin yapıldığı ve bu vesile ile mimari eserlerin padişahın adı ile "tevsim" edildiği, yani isimlendirildiği bilinmektedir. 
cağında inşa kılınıp padişahın adı ile isimlendirilen hastanenin daimi masraflarına karşılık olmak üzere alınacak vergi hakkında yapılan yazışmada, hastaneden frengi hastanesi olarak bahsedilmektedir. Isparta Sancağı'ndaki hastane, "gurebâ ve biçaregânın mahafaza-i sıhhatleri ile hükmü ferman olan frengi illetinin men'i” maksadıyla inşa edilip padişahın adıyla isimlendirilmiştir (BOA., Y.A.RES., 132/87, 22 Cemaziyelevvel 1323, 25 Temmuz 1905). Bu dönemde yaygınlaşan frengi hastalığ1 sebebiyle yeni frengi hastaneleri inşa etmenin yanında, mevcut hastanelerin bu hastalığın tedavisine tahsis edildiği veya buralara frengi pavyonlarının eklendiği bilinmektedir (Yazıc1 Metin 2020a: 255).

\section{Hastanenin Mimari ve Süsleme Özellikleri:}

Günümüze ulaşmayan Isparta Gurebâ Hastanesi'nin mimarisi hakkında, Hamidabad Nafia mühendisi mühürlü, R. 30 Teşrin-i evvel 1319 (M. 12 Kasım 1903) tarihli Keşif Defteri ile ekindeki, "Isparta'da müceddeden inşa edilecek hastahanenin resmi" açıklamasının yer aldığı kat plânları ve cephe çizimlerinden; ayrıca bu çizimlere göre uygulandığını gösteren fotoğrafindan bilgi edinilebilmektedir (BOA., DH.MKT., 816/54; BOA., FTG., No: 1703). Keşif Defteri üzerinde, "Taraf-1 acizanemce resmedilmiştir, 30 Teşrin-i evvel 319, Hamidabad Nafia Mühendisi" açıklaması ve "Kalfaoğlu Mühendis Yanko" mührü okunmaktadır (Foto 1). Aynı açıklama ve mühür hastanenin plân ve çizimlerinin alt köşesinde de yer almaktadır (Çiz. 1-2).

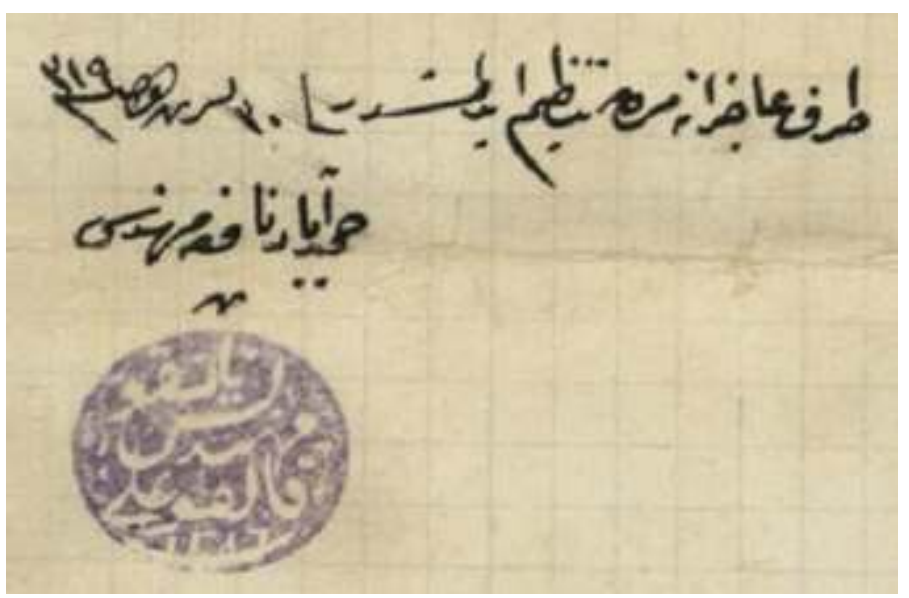

Foto 1. Hastanenin Keşif Defteri üzerindeki "Hamidabad Nafia Mühendisi” açıklaması altındaki Kalfaoğlu Mühendis Yanko mührü. (Kaynak: BOA. DH.MKT., 816/54, 30 Teşrin-i evvel 319, 12 Kasım 1903). 
Isparta Gurebâ Hastanesi'nin Keşif Defteri, günümüze ulaşmayan hastanenin inşaat sürecini ve masraflarını göstermesi açısından önemlidir. Defterdeki tanımlamayla, sırasıyla etraf beden duvarları, iki kule ve bölme duvarlarının temel harfiyatı; etraf duvar temelleri ile iki kule temellerinin inşası; alt kat duvarları ile etraf ve iki kule duvarlarının, ayrıca bölme duvarlarının inşası; üst katta etraf duvarları, iki kule ve bölme duvarlarının inşası ayrıntılı olarak tanımlanmıştır. Ayrıca yapıda kullanılacak ahşap inşaat, alt ve üst katın bağdadi bölmeleri; alt ve üst katın taban, tavan inşası; sakıf, merdiven, cümle kapısı, dahili kapılar, "umum binanın pencereleri", söveler, "cümle kapılarının önüne taştan merdiven inşası", "banyo odalarına mermer döşeme inşası", kaba yonu inşaat gibi masraf kalemlerine de yer verilmiştir. Keşfe göre inşaatın toplam masrafı 114712,07 kuruş tutacaktır (BOA., DH.MKT., $816 / 54)$.

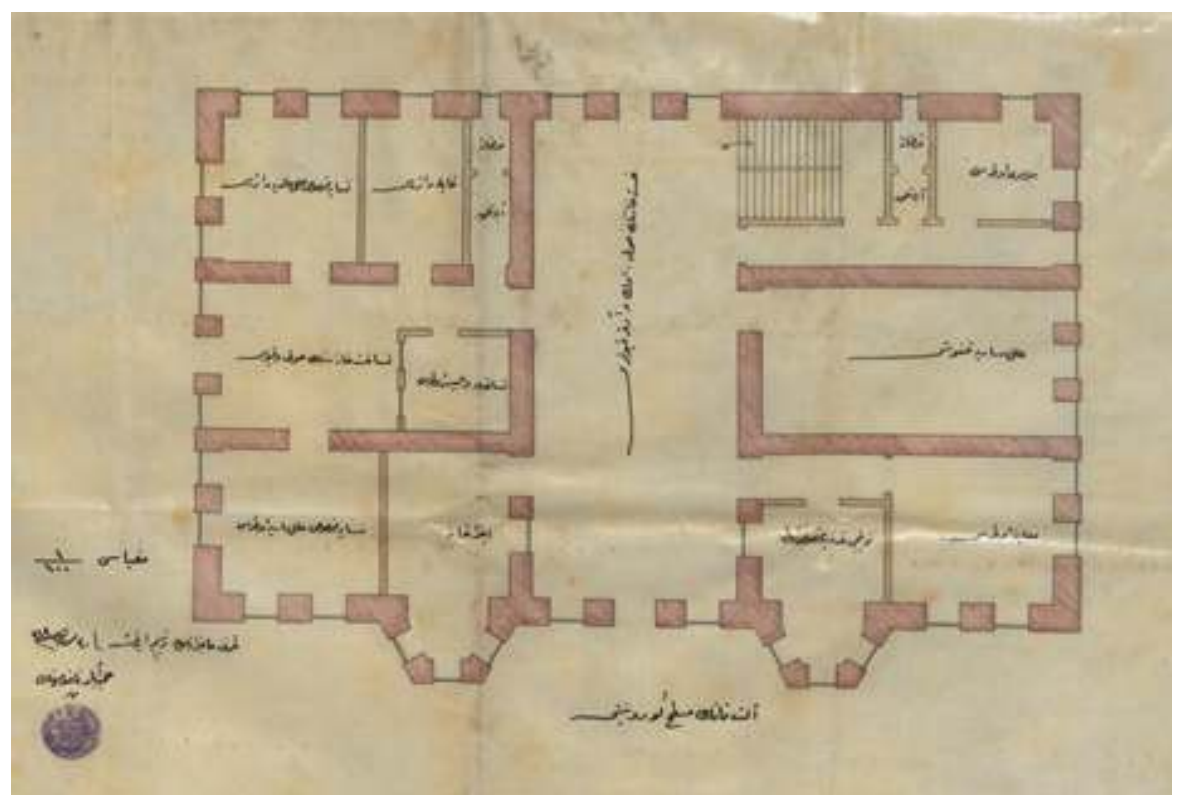

Çiz. 1. Isparta Gurebâ Hastanesi'nin 1903 tarihli Keşif Defteri ekindeki alt kat plânı. (Kaynak: BOA., DH.MKT., 816/54, 30 Teşrin-i evvel 319, 12 Kasim 1903). 


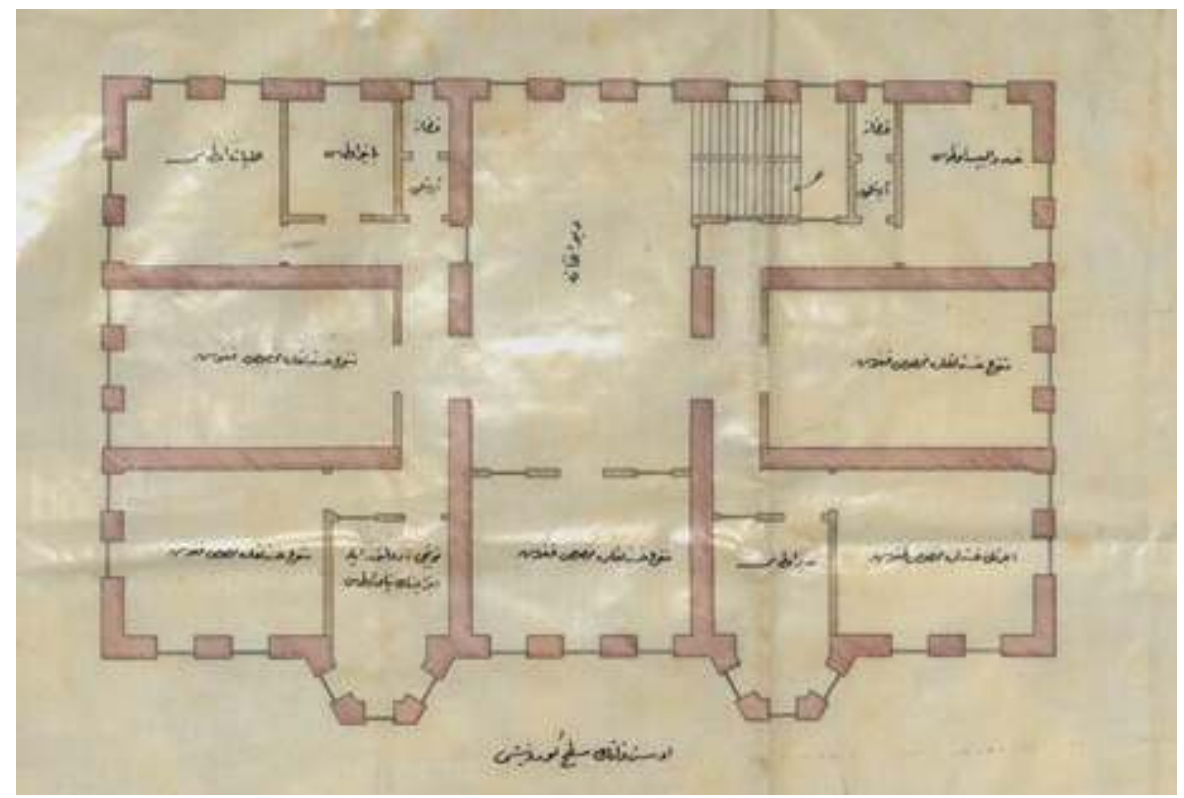

Çiz. 2. Hastanenin üst kat plânı. (Kaynak: BOA., DH.MKT., 816/54, 30 Teşrin-i evvel 319, 12 Kasım 1903).

Isparta Gurebâ Hastanesi, mevcut çizime göre dikdörtgen şemada, iki kat1, her iki katta da mekân dağılımının, çizimde "avlu" olarak tanımlanan ve geniş tutulduğu görülen orta koridora göre yapıldığı bir plâna sahiptir (Çiz. 1-2). Orta avlu/koridor binanın dar kenarlarına göre orta alana yerleştirilmiş; iki yanında, dar kenarlar boyunca odalar ve koğuşlar sıralanmıştır. Alt kat plânında, cephe ortasındaki yarım kule düzeniyle vurgulanan genişlik boyunca orta avlu uzanmaktadır. Bu alanda "Hastahanenin avlu, ön ve arka kapıları" yer almaktadır. Plân üzerindeki tanımlamalardan, orta avlunun batı yönünün, "kadın hastalara mahsus" olduğu anlaşılmaktadır. Burada, girişin solunda, "Eczahane, nisâya mahsus ilel-i sâriye (bulaşıcı hastalıklar) odası", arkasında "nisâ hastahanesinin avlu ve kapısı" ile köşesinde "nisâ hademe odası" bulunmaktadır. Arka cepheye nazır üçlü mekânda ise "nisâya mahsus ilel-i adiye dairesi, dairesi, kademehane, aydınlık" mekânları vardır. Orta avlunun doğu yönünde "növbetçi hademeye mahsus oda, muayene odas1, ilel-i sariye koğuşu, serseri (?) odası, aydınlık" mekânları görülmektedir. Üst kat bağlantısını sağlayan çift kollu mervivenler, arka girişin doğu yönünde bulunmaktadır (Çiz. 1).

Hastanenin üst kat plânında, "mütennevvi (çeşitli) hastalıklara mahsus" dört büyük koğuş ile "ücretli hastalara mahsus" bir koğuş bulunmaktadır (Çiz. 2). Bu 
katta kule mekânları, "müdür odası ve nöbetçi doktor ile eczacının yatak odası" olarak tanımlanmıştır. Arka cephenin batı yönü ameliyat odası, banyo odası; doğu tarafı ise hademe ve elbise odası gibi hizmet mekânlarına ayrılmıştır.

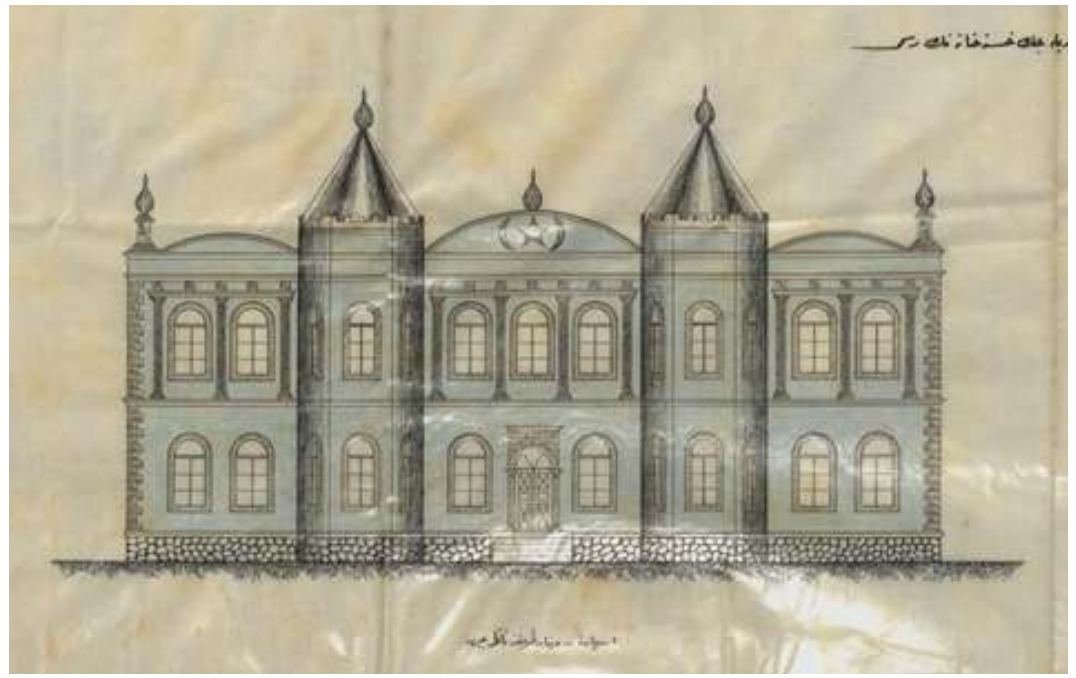

Çiz. 3. Isparta Gurebâ Hastanesi'nin ön cephe çizimi. (Kaynak: BOA., DH.MKT., 816/54, 30 Teşrin-i evvel 319, 12 Kasım 1903).

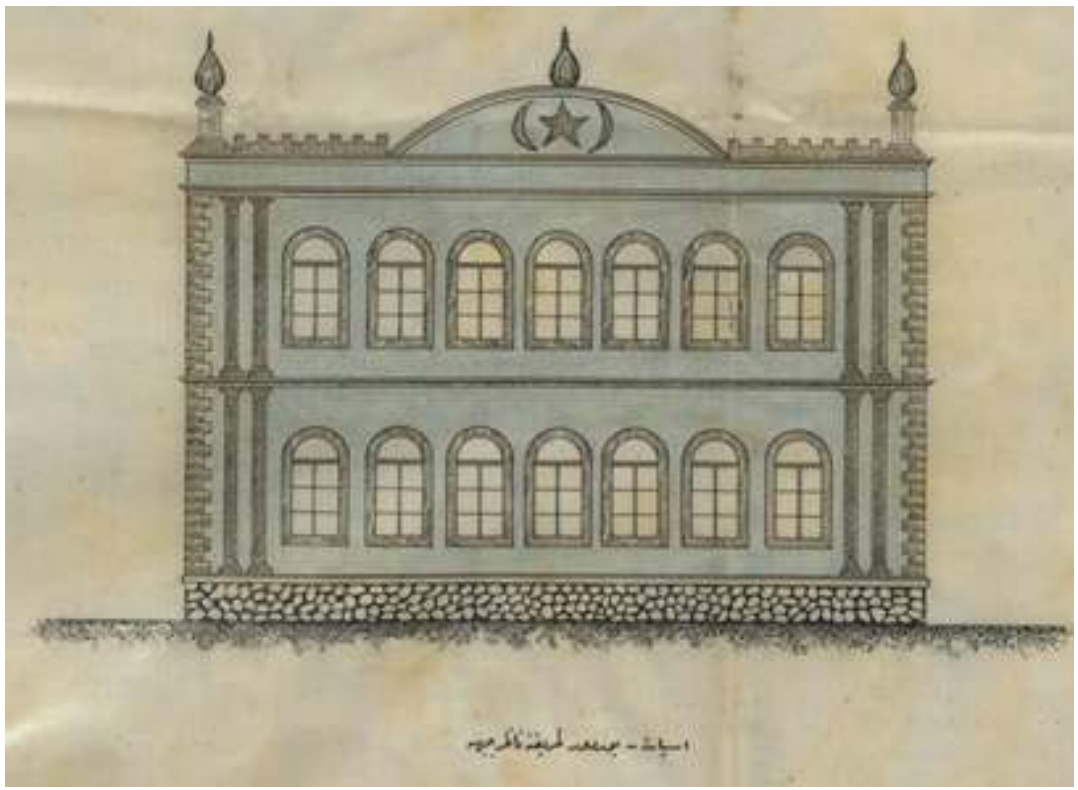

Çiz. 4. Hastanenin yan cephe çizimi. (Kaynak: BOA., DH.MKT., 816/54, 30 Teşrin-i evvel 319, 12 Kasım 1903). 
Hastanenin ön cephesi silmelerle kat ayrımlarının verildiği ve sık pencere açıklıklarının kullanıldığı bir görünümdedir (Çiz. 3). İki katlı cephe dikeyde üç bölüm halinde düzenlenmiştir. Cephe ortasında, katlar boyunca devam eden iki yarım kulenin sınırlandırdığ 1 alanda, alt katta, Keşif Defterinde “cümle kapısı" olarak tanımlanan kapı açıklığı ve iki yanında birer pencere; üst katta ise üç pencereye yer verilmiştir. İki katta da üçer penceresi bulunan, üç köşeli kuleler, beden duvarlarını aşmaktadır ve üzerleri külahla örtülmüştür. Bu köşeli yarım kulelerin iki yanında, katlarda ikişer pencere açıklığının bulunduğu görülmektedir. Cephe, ortadakinin daha büyük tutulduğu yarım dairevi alınlıklarla son bulmaktadır. Orta alınlıkta ay-yıldız (ortada yıldız, yanlarda birer ay) motifi kullanılmıştır. Subasman katının kotuna bağlı olarak basamaklarla ulaşılan ana giriş ve pencerelerin tamamı yarım daire kemerlidir. Ön cephe çiziminde, üst kat pencere aralarındaki plastır düzeni dikkati çekmektedir.

Çizim üzerinde "Isparta-Burdur tariğine nazır ciheti" açıklamasının olduğu yan cephede de kat ayrımları silmelerle verilmiştir (Çiz. 4). Her iki katta, ön cephe ile aynı düzende yedişer pencere kullanılmıştır. Burada, her iki katta, yanlarda, pencerelerin bitimindeki ikişerli plastır uygulamaları görülmektedir. Bu cephenin bitiminde de ön cephe ortasındaki ay yıldızlı alınlık düzeni tekrarlanmıştır. Ayrıca ön cephedeki yarım kulelerde ve yan cephede beden duvarlarının bitiminde, askeri mimariye özgü dendan kullanılmıştır. 


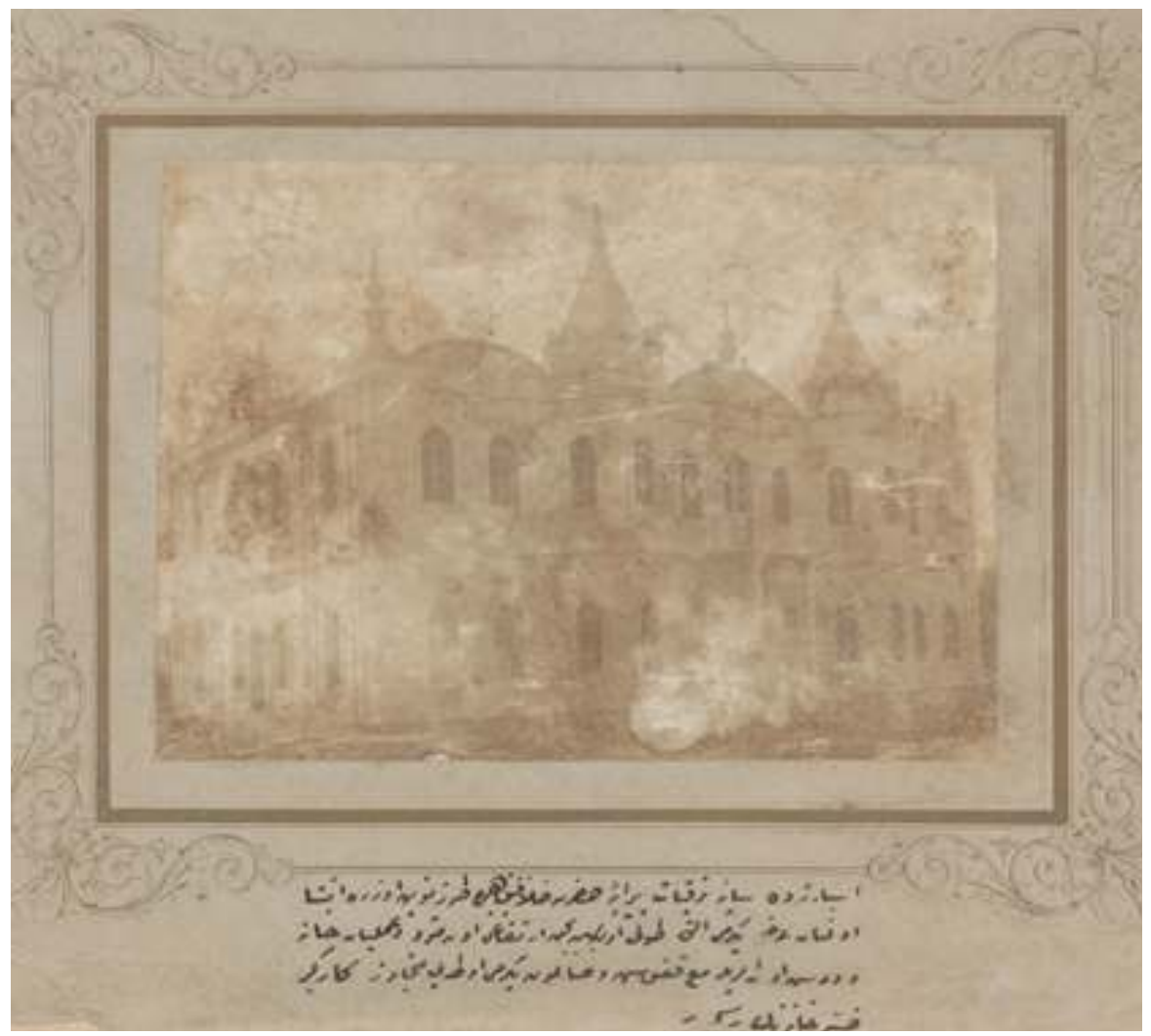

Foto 2. Isparta Gurebâ Hastanesi'nin inşa edildiği dönemden fotoğrafi. (Kaynak: BOA., FTG., No: 1703).

Cephe çizimlerinden neoklasik üslupta olması planlanan hastane binasının küçük farklılıklarla uygulandığı, dönemindeki mevcut fotoğrafından anlaşılmaktadır (Fot. 2). Fotoğraftan da kat ayrımlarında korniş/silme kullanımı ile söveli, yarım daire kemerli pencereler ve üst kattaki plastır düzeni görülebilmektedir. Bina cephesinde, orta aksta kapı açıklığının bulunduğu kısım üst katta da aynı genişlikte öne çekilerek iki sütun üzerine taşınan balkon şeklinde düzenlenmiştir. Bu kattaki orta pencere kapı olarak bırakılmıştır. Uygulamada yer verilen bu ayrıntı cephe çiziminde gösterilmemiştir. Ayrıca fotoğrafta, çizimde mevcut olmayan diğer yan cephe görülebilmektedir. Burada, diğer cephenin aksine, üst katta, ortadaki üçlü düzende olmak üzere arada boşluk bırakılarak yanlara birer pencere eklenmiş ve beş pencere şeklinde uygulanmış; aynı düzenin tekrarlandığı alt katta ortadaki pencere tali kapı olarak düzenlenmiştir (Foto 2). Plân çiziminde tanımlandığı üzere bu 
kısım kadın hastalara mahsustur. Dönemin hastane mimarisinde sık aralıklı küçük pencere açıklıklarının kullanıldığı yüksek subasman katı ya da bodrum katının burada kullanılmadığı görülmektedir. ${ }^{6}$

Fotoğrafin altında birtakım açıklamalar bulunmaktadır (Foto 2). Hastane "tarz-1 nev' üzre", yani yeni tarzda inşa edilmiş kargir bir yapıdır ve arzı (eni) 26, tuli (boyu) 15,5 ve irtifai (yüksekliği) 10 metredir. Hastane ameliyathane, duş odaları, koğuş ve salonla yirmi odayı geçmektedir.

Isparta Gurebâ Hastanesi, yukarıda da tanımlandığı üzere günümüze ulaşmamıştır. 1914 yılında yaşanan büyük depremde büyük oranda hasar gördügü anlaşılan bina yıktırılmıştır (Besim Zühdü 2013: 29). Ancak hastanenin fotoğrafına yer verilen bazı yayınlarda burası "Askerlik Dairesi” olarak tanımlanmış ve binanın değişikliklerle günümüze ulaştığı yazılmıştır. Böcüzade Tarihi'nin, günümüz diline aktarılarak özetlenen ve birtakım fotoğraflar eklenen baskısında Mutasarrıf Hüsnü Bey'in döneminin anlatıldığı bölümde "Isparta askerlik dairesinin 1904'deki ilk şekli (halen mevcut)" şeklinde açıklamanın bulunduğu hastanenin eski bir fotoğrafına yer verilmiştir (1983: 256). Aynı fotoğraf 2001 y1lında Isparta Valiliği'nin yaptığı yayında da "Isparta Askerlik Dairesi Şimdiki Tümen Karargah Binası 1904” açıklaması ile kullanılmış; bu açıklamaya cephe ayrıntısındaki bir onarım fotoğrafı eklenerek "Tümen Karargah Binası Onarımı. 1904 yılında yapılan bina 1934 yılında çıan bir yangın sonucunda tahrip olmuş ve bugünkü şekli ile onarılmıştır (1934)" bilgileri eklenmiştir (Komisyon 2001: 53). Bahsi geçen her iki yayında da kullanılan fotoğraf Isparta Gurebâ Hastanesi'nin fotoğrafıdır ve Askerlik Dairesi ile alakası yoktur.

Gurebâ Hastanesi ile karıştırıldığ 1 anlaşılan Askerlik Dairesi de aynı dönemde, Mutasarrıf Hüsnü Bey zamanında inşa edilmiştir (Foto 3). Nitekim 1901 tarihli bir yazışmada, "Isparta'da inşa edilmekte olan daire-i askeriye hitam bulunduğundan cülûs-1 hümâyuna" tesadüf eden günde küşadının icrası karalaştırılmıştır (BOA., Y.PRK.BŞK., 65/9, 8 Cemaziyelevvel 1319, 23 Ağustos 1901). Dolayısıyla buradaki daire-i askeriye farklı bir binadır; birçok fotoğrafta görülen ve depremden kısmı zararla kurtulduğu anlaşılan bu bina onarımlarla günümüze gelmiştir (Komisyon 2009: 175). Bu binanın gurebâ hastanesiyle ilgisi yoktur.?

Dönemin birçok hastane örneğinde, küçük tutulmuş bodrum kat pencereleri kullanılmıştır. Bolu, Samsun, Dedeağaç Gurebâ Hastaneleri bu örnekler arasındadır. Bakz. Yazıcı Metin 2019a: 53; Yazıc1 Metin 2020b: 954.

7 Isparta'da Kutlubey Mahallesi, eski kent dokusunun olduğu alan hükümet konağı ve çevresi, bütün yapıların konumlandığı alandır. Kışla, askeri depo, daire-i askeriye, hapishane bu çevrededir. 1914 
Askerlik Dairesi ya da Karargah Binasının eski fotoğrafı olarak tanımlanan, günümüze değişikliklerle ulaştığı ifade edilen ve fotoğraflarda görülen binanın Isparta Gurebâ Hastanesi'nin eski bir fotoğrafi olduğu kesindir ve günümüze değişikliklerle gelen askerlik dairesi ile ilgisi yoktur. Bu fotoğraflar, hastanenin inşa edildikten bir süre sonra onarım geçirdiğini düşündürmektedir. Nitekim inşa edildiği dönemin fotoğrafında açık bir şekilde uygulandığı anlaşılan ön cephedeki beden duvarlarını aşan külahla örtülü kuleler ve yan cephe alınlıklarının burada kaldırıldığı görülmektedir (Foto 4). Buradaki değişikliğin, 1911 yılındaki tamirle ilgili olması muhtemeldir. Isparta Gurebâ Hastanesi'nin 1911 y1lında tamiri söz konusudur. Tamirat için gerekli tahsisatın sağlanması yönündeki yazışmada tamirata dair bir ayrıntı verilmemiştir (BOA., DH.İD., 47/32, 14 Zilhicce 1329, 6 Aralık 1911).

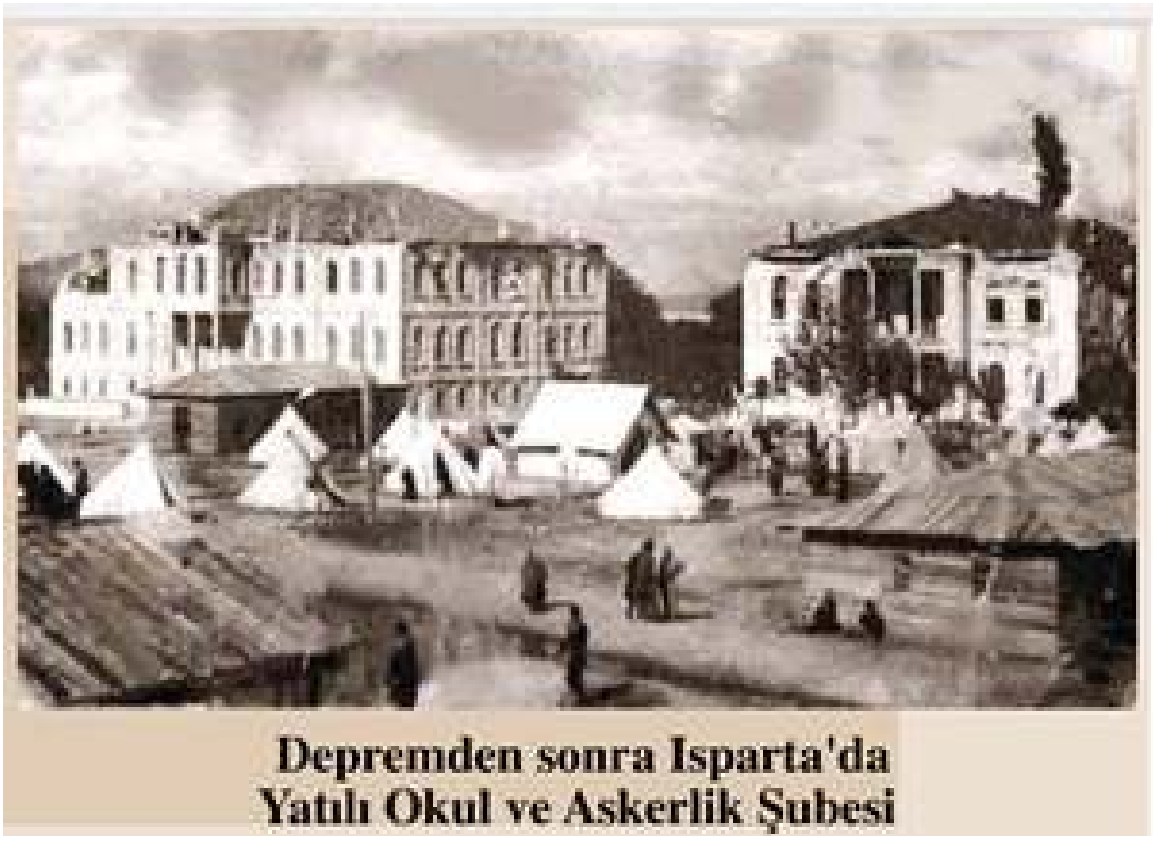

Foto 3. 1914 tarihinde yaşanan depremde zarar gördügü anlaşılan ve günümüze değişikliklerle gelen Mekteb-i İdadi yanındaki askerlik dairesinin deprem sonrası durumunu gösteren fotoğraf. (Kaynak: Komisyon 2001: 24). 


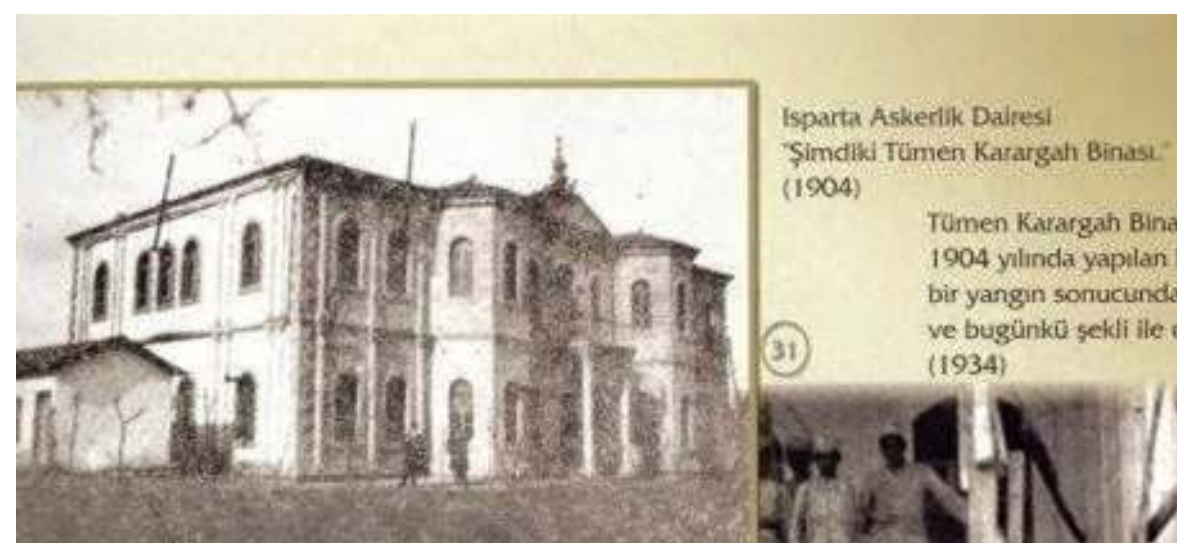

Foto 4. Isparta Gurebâ Hastanesi'nin, yanlışlıkla Askerlik Dairesi olarak tanımlanan fotoğraftaki görünümü. (Kaynak: Komisyon 2001: 53).

\section{Değerlendirme:}

Dönemin padişahı Sultan II. Abdülhamid'in adına izafeten Hamidiye Gurebâ Hastanesi olarak da anılan Isparta Gurebâ Hastanesi'nin inşasına, 1903 yı1ı sonlarında başlanmış; 1904 yılı 1 Eylül tarihinde de resmi açılışı yapılmıştır. Hastane belediye adına satın alınan bir arsa üzerine, "minnettar ahalinin" yardımlarıyla inşa edilmiştir. Diğer gurebâ hastanelerinde olduğu gibi buraya da daimi masraflar için birtakım gelirler tahsis edilmiştir.

Isparta Gurebâ Hastanesi, kargir, dikdörtgen kurguda, orta avlu/koridor iki yanına yerleştirilen mekânların kullanıldığı bir plân şemasına sahiptir. Bu plân şemasının, daha çok uzun kenarlar boyunca uzanan orta koridor kurgusunda, dönemin birçok yapısında kullanıldığı bilinmektedir. ${ }^{8}$ Osman1 mimarlığındaki referansı iç sofalı plân tipinde görülebilen bu şema, son dönem Osmanlı mimarlığındaki kamu yapılarında karşılığını, dönemin plân çizimlerindeki tanımlamayla "koridor", "avlu", "salon" olarak bulmaktadır.9 Isparta Gurebâ Hastanesi'ndeki, dar kenarlar boyunca orta alana yerleştirilen avlu/koridor düzeni, buradaki plân şemasına çok benzer bir kullanımla Makedonya Debre'deki hastane binasında görülebilmektedir (Foto 5).

$\overline{8}$ Dönemin farklı yapı türlerindeki örnekler için bakz. İgüs 2016: 293-315; Yazıcı Metin 2019b: 124125 .

9 İç sofalı plân şeması, dönemin hastane mimarlığını örnekleyen tanım ve çizimlerin yer aldığı askeri mimarlık kitaplarında da yer almaktadır. Bakz. Ahmed Şükrü, 1883, 36, 38. Dönemin hastane mimarisinde de pekçok örneği mevcuttur. Yazıcı Metin 2020b: 957. 


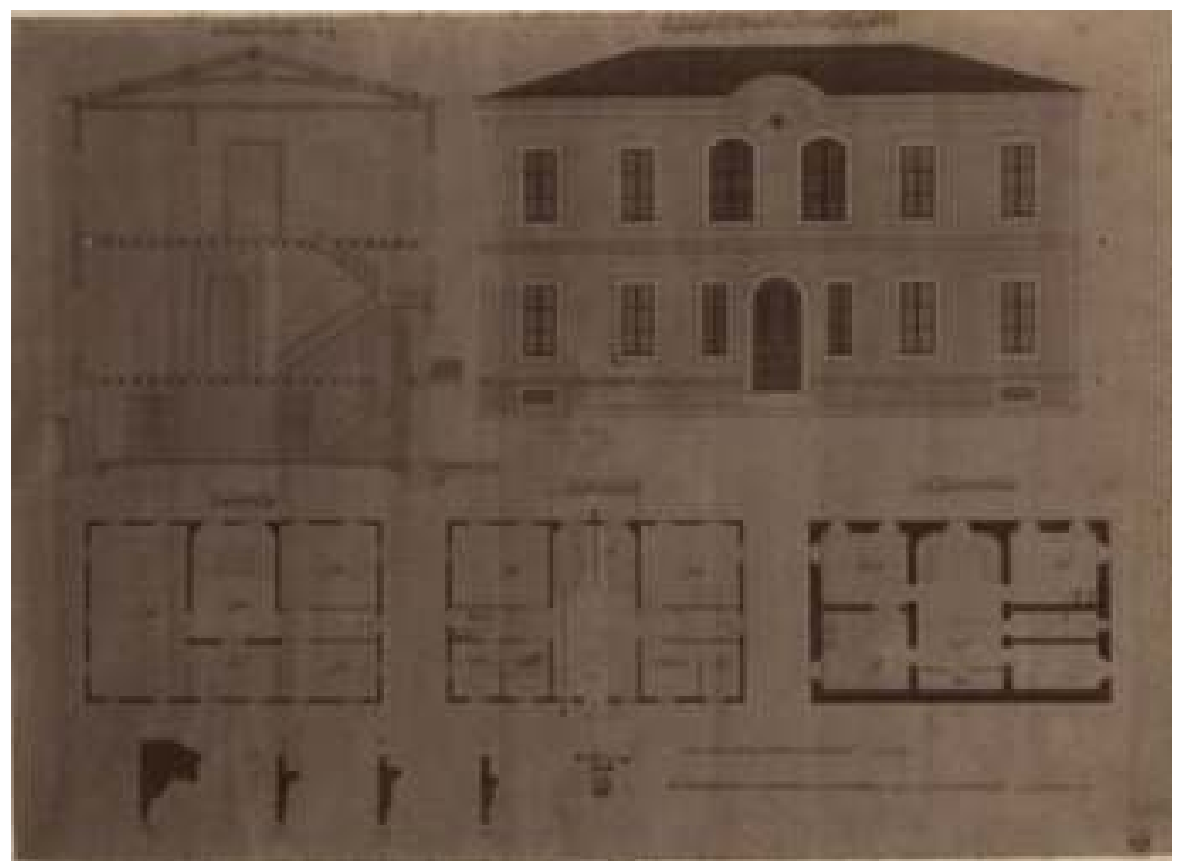

Foto 5. Makedonya, Debre Topçular'daki hastane binasının çizimleri. (Kaynak: İ.Ü., Nadir Eserler Kütüphanesi, II. Abdülhamid Albümleri, No:90441.0032).

Isparta Gurebâ Hastanesi, oldukça simetrik bir plân ve cephe düzenine sahip neoklasik üslupta bir yapıdır. Dönem mimarisinde yaygın olarak kullanılan neoklasik üslup, hastane mimarisinde de uygulanmıştır. Isparta Gurebâ Hastanesi'nin cephe kurgusunda, girişin iki yanında, bina yüksekliğini aşan, çokgen kesitli iki yarım kule bulunmaktadır. Neoklasik üslupta, cephe ortası ve iki kenarının öne çekilerek kurgulanması yaygındır. Aynı şekilde Birinci Ulusal Mimarlık üslubunda da bu uygulamalar görülmektedir. Cephe köşelerine yerleştirilen kuleler de dönem mimarlığında, farklı üsluplarda uygulanmıştır. Ancak burada olduğu gibi ana girişin iki yanında kulelerin yer alması çok yaygın bir uygulama değildir. Benzer bir uygulama, aynı vilayet dahilinde, 1901 yılında açılan Konya'daki Sanayi Mektebi cephesinde görülmektedir (Fot. 6). Sanayi Mektebi, vilayet ser-mühendisi Şefik Bey tarafından, vali Ferit Paşa zamanında, 1901 yılı Eylül ayında hizmete açılmıştır (Fırat 2005: 360). Birinci Ulusal Mimarlık üslubunun erken tarihli bir uygulamas1 olarak kabul edilen Sanayi Mektebi'nden sonraki bir tarihte (Sözen 1984: 41), benzer cephe düzenlemesinin, aynı vilayet dahilindeki sancak hastanesinde, bu defa neoklasik üslupta ele alındığı anlaşılmaktadır. 
Girişin iki yanında kullanılan kulelerle cephedeki "giriş" vurgusu, yukarıda da belirtildiği gibi çok yaygın olmamakla birlikte dönemin farklı üsluplardaki bazı yapılarında kullanılmıştır. Çokgen kulelerle girişin belirlendiği, erken tarihli abidevi bir uygulama, 1806'da inşa edilen, oryantalist bileşenlerle şekillenen Taksim Topçu Kışlası'nın 1860'lı yıllardaki eklerinde, onarımında görülmektedir. Sirkeci Garı'nın (1890) abidevi girişi iki yanındaki kule düzenlemeleri, 1903'te açılan Haydarpaşa Mekteb-i Tıbbiye-i Şahane cephesindeki kuleler bu anlamda akla gelecek ilk örneklerdendir. Sirkeci Büyük Postane (1909) cephesindeki çokgen kuleleri Birinci Ulusal Mimarlık Dönemi'nin birçok yapısı takip etmektedir (Sözen 1984: 34-41). 1910 yılında hizmete açılan Edirne Garı cephesi ortasındaki giriş iki yanındaki kuleler de bu uygulamanın örnekleri arasındadır. ${ }^{10}$

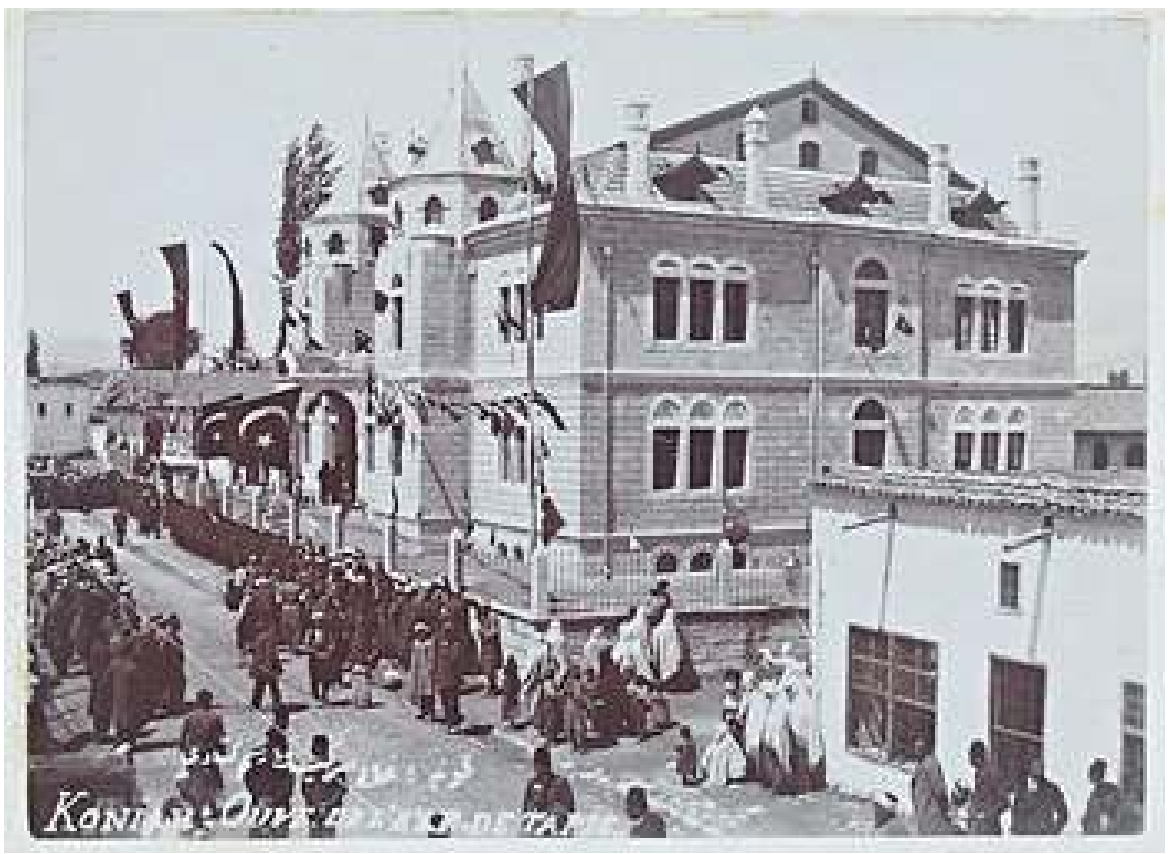

Foto 6. Konya Sanayi Mektebi (Kaynak: İ.Ü. Nadir Eserler Kütüphanesi, II.Abdülhamid Albümleri, No:779.77.0046).

$\overline{10}$ Sirkeci ve Edirne Gar binaları aynı zamanda köşe kulelerinin kullanıldığı örneklerdir. 1926 tarihli Ankara Gazi Garı da giriş iki yanında kulelerin kullanıldığı bir başka uygulamadır. Gar binalarında sık rastlanan bu uygulama için bakz. Başar ve Erdoğan 2009: 29-43. 
Hastane mimarisinde, giriş iki yanında kulelere yer verilmesi ya da cephe köşelerinde kule kullanımı Haydarpaşa Mekteb-i Tıbbiye-i Şahane binasında farklı bir düzende görülmektedir. Biraz daha farklı bir kurguda olmakla birlikte, girişin iki yanında kulelerin kullanıldığı bir diğer bina, bugün İstanbul Üniversitesi'nin Çapa Tıp Fakültesi yerleşkesi içinde kalan, Vakıf Gurebâ Hastanesi'ne sonradan eklenen pavyonlardan biri olan ve temeli 1911 yilında atılan yönetim binasıdır (Yavuz 1988: 129, 137). Cephe köşelerine yerleştirilen kule düzeni ise Hamidiye/Şişli Etfal Hastanesi'nin yönetim binası (1898) olarak inşa edilen ve günümüze ulaşmayan pavyonu (Foto 7), Urfa Zükur ve İnas Gureba Hastanesi cephesinde de görülebilmektedir.

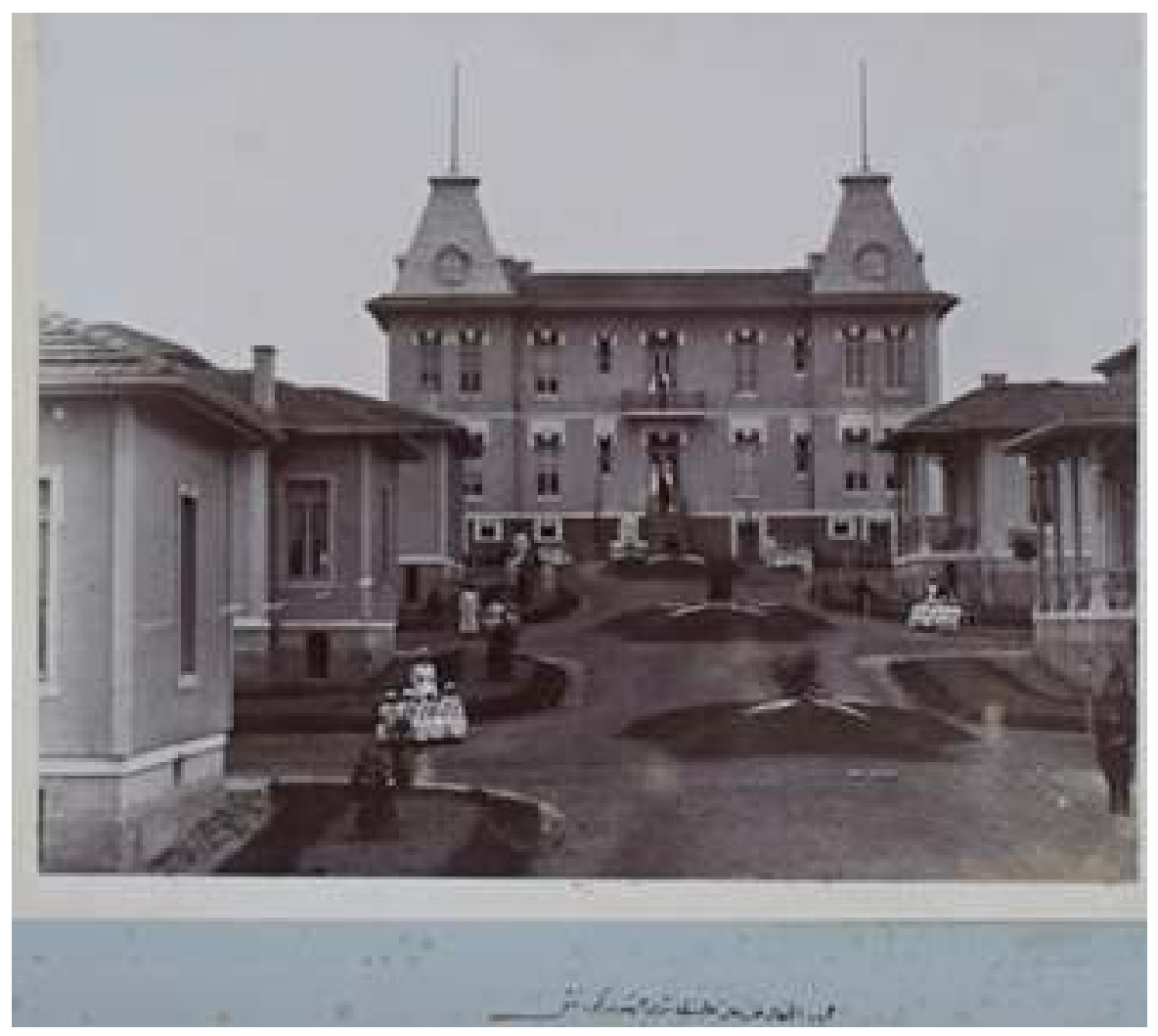

Foto 7. Hamidiye /Şişli Etfal Hastanesi (İ.Ü. Nadir Eserler Kütüphanesi, II. Abdülhamid Albümleri, No: 779.42-0006)

Isparta Gurebâ Hastanesi, sancağın nafia mühendisi Kalfaoğlu Yanko tarafından tasarlanmıştır. Bu bilginin mevcut Keşif Defteri ve plânlar üzerinde yer alması, dönemin hastane binalarını tasarlayan isimler hakkında bilgi vermesi 
açısından önemlidir. Sancağın nafia mühendisi olan Kalfaoğlu Yanko'nun, aynı dönemde yeni baştan kargir olarak yapılan Isparta'daki Kutlu Bey Camisi'nin (Ulu Cami) tasarımını yaptığı ve inşaatını da yürüttüğü anlaşı1maktadır. ${ }^{11}$ Caminin yeniden inşasında "hüsn-i hizmeti görülen Nafia mühendisi Kalfaoğlu Yanko Efendi" taltif edilmiş; yirmi beş lira değerinde bir altın saat zarfına "Isparta Camii-i Kebir-i Cedidine inşada hüsn-i hizmeti görülen Kalfaoğlu Yanko Efendi’ye Ispartalıların hediyesidir” ibaresi hakk ettirilmiş;; bir kat elbiseyle beraber resmi küşad günü kendisine verilmiştir. Burada mühendis Yanko Efendinin Gurebâ Hastanesi'nin inşasından sonra Isparta'da vefat ettiği bilgisine de yer verilmiştir. Caminin 1 Eylül 1902 tarihinde, cülus günü açılışında, inşaat komisyon adına okunan manzum nutukta da iki mısrada "nafia mühendisi Kalfaoğlu Rekriye Yanko/Yaptı bir resm-i mükemmel Tanrı ber hoş eyleye" ifadesi geçmektedir (Böcüzade 2012: 116-117). Sancağın nafia mühendisi olan Kalfaoğlu Yanko'nun, bu dönemde Isparta'da inşa edilmiş olan başka yapıların tasarımcısı da olması muhtemeldir.

Isparta Gurebâ Hastanesi, mutassarrıf Hüsnü Bey zamanında, onun girişimleriyle inşa edilmiştir. İstanbul Polis Müdürlüğü görevinden H.1312 (M.1894) tarihinde Isparta mutasarrıflığına getirilmiş olan Hüseyin Hüsnü Bey, 10 yıl boyunca bu görevde bulunmuş; H. 1322 (M. 1904) senesinde de Teke Sancağı mutasarrıflığına nakledilmiştir. Isparta'nın imarında önemli bir rol oynayan Hüsnü Bey, "Isparta'da maabid ve maarif ve sanayi' ve terakkiyat-1 dahiliye" için birçok girişimde bulunmuş; hastane, hapishane, jandarma koğuşu ve ahırı, daire-i askeriye, telgrafhane, darül-muallimin, mekatib-i ibtidaiye ile "gülyağcılık, halıcılık, maarif akaratı ve ipekli mensucat vücuda getirilmesi" gibi birçok başarıya mazhar olmuş ve Isparta'da unutulmayacak eserler bırakmış bir isim olarak tanımlanmıştır (Böcüzade 2012: 119, 267, 647).

Böcüzade Tarihi'nde, mutasarrıf Hüseyin Hüsnü Bey tarafından caminin tamamen yıktırılıp Sultan II.Abdülhamid'in yirmi beşinci cülusunda açılmak üzere Ayasofya plânında yeniden inşa edildiği ve 1 Eylül 1902’de, sonraki cülus günü açıldığı yazılıdır. Bakz. Böcüzade 2012: 113-115. 


\section{SONUÇ}

Yönetim sistemi ve yaşam biçimindeki değişimin yaşandığı Osmanlı’nın son döneminde, bu değişimin fiziksel yansıması olarak inşa edilen yeni yapı türleri arasında sivil hastaneler de vardır. Modern sağlık hizmetlerinin sivil halk nezdinde uygulandığı yerler olan ve dönemindeki özelleşmiş isimlendirmeyle "gurebâ hastahaneleri" şeklinde tanımlanan hastanelerin bir örneği de bu dönemde Konya Vilayetine bağlı Hamidabad sancağında, sancağın merkezi olan Isparta'da, 1904'te inşa edilmiştir. 1914 y1lında yaşanan deprem sonras1 yıkılarak/yıktırılarak günümüze ulaşmayan bu hastane binası, ulaşılan orjinal çizimleri üzerinden değerlendirildiğinde, plân şemas1 ve özellikle cephe kurgusu açısından dikkat çekici bir örnek olduğu görülmüştür. Plân şemasında, orjinal çizimler üzerinde tanımlandığ 1 şekliyle "avlu"/ koridora göre şekillenen bina koğuş, eczahane, muayene odası, doktor odası, hizmet mekânları gibi bileşenleriyle dönemin hastane mimarisindeki mekân dağı11mını örneklemektedir. Aslında dönemin yaygın üslubu olan neoklasik üslupta bir yapı olan hastane genel cephe biçimlenişi; giriş iki yayına yerleştirilen kulelerin kullanımı ile alışılan kuleli cephe düzeninden biraz farklıdır.

Hastanenin plân şeması ve mekân dağılımı, bu dönem hastane mimarisinin tek bir kaynaktan şekillenmediğini göstermektedir. Osmanlı'nın son döneminde inşa edilen modern hastanelerin mimarisinde, dönemin batılı hastane modellerinin örnek alınmasının yanında askeri mimarlık kitaplarında tanımlanan şemalar ve de Osmanlı konutunun referans oluşturduğu anlaşılmaktadır. Isparta Gurebâ Hastanesi de gerek plân şeması, gerekse mekân dağglımı ve cephe düzeni ile bütün bu bileşenleri örnekleyen bir yapıdır. Ayrıca binanın tasarımcısının biliniyor olması, bu dönem hastane yapılarının kimler tarafından tasarlandığını, uygulandığını göstermesi açısından önemlidir. 


\section{KAYNAKLAR:}

Ahmed Şükrü (1883). Fenn-i Mimari, Piyade ve Süvari stnıflarına mahsus ve programına muvafik, 1300 H./1883. (Erişim tarihi: 9 Ekim 2019), http:// ataturkkitapligi.ibb.gov.tr

Başar, M. Emin ve H. Abdullah Erdoğan (2009). "Osmanlı'dan Cumhuriyet'e Türkiye'de Tren Garları”, S.Ü. Müh-Mim Fak. Dergisi, c. 24, s. 29-43.

Besim Zühdü (2013). Türkiye'nin Sıhhi-i İçtimai Coğrafyası, Hamidabad (Isparta) Sancağı, Hazl. Hasan Babacan, Kadir Temurçin, Ankara: Altınpost Yayincilık.

Böcüzade Süleyman Sami (1983). Isparta Tarihi, Birinci ve İkinci Cilt, Yayl. Suat Seren, İstanbul: Serenler Yayını.

Böcüzâde Süleyman Sami (2012). Isparta Tarihi, Haz. H. Babacan, Isparta: Isparta Valiliği Yayını.

Demirci, Serpil (2009). "Tarihsel Süreçte Isparta'da Sağlik Hizmetleri", Geçmişten Günümüze Isparta, Ankara: Atatürk Kültür Merkezi Yayını, s. 163-171.

Duymaz, A. Şevki (2009). "Isparta ve Çevresinde Yer Alan Türk Dönemi Eserleri”, Geçmişten Günümüze Isparta, Ankara: Atatürk Kültür Merkezi Yayın1, s. 203-226.

Emecen, Feridun (1999). "Isparta", İslam Ansiklopedisi, cilt: 19, İstanbul: Türkiye Diyanet Vakfi Yayını, s. 194-200.

Fırat, Nurcan İnci (2005). "Konya'daki Eski Sanayi Mektebi", Vakıflar Dergisi, 29, s. 345-371.

İgüs, Esma (2016). "II.Abdülhamid Dönemi Askeri Rüşdiyelerini Mimari Planları Üzerinden Okumak", Sosyal ve Liberal Bilimlerde Yeni Yönelimler I. (Ed. H. Babacan, S. Özer). Ankara: 293-315.

Komisyon (2001). Isparta 1880-1980, Isparta: Isparta Valiliği.

Komisyon (2009). Isparta Kültür Envanteri, cilt 1, Isparta: Isparta Valiliği.

Komisyon (2014). Cumhuriyetin XV.Y1lında Türkiye, yay. Hazl. İ. Öztoprak, 4. Cilt, 2014.

Sözen, Metin (1984). Cumhuriyet Dönemi Türk Mimarlığı, Ankara: İş Bankası Yayınları. 
Türk, Ali ve Huriye Öçal (2007). "Isparta Kenti Konut Dışı Sivil Mimari Yapıları ve Özellikleri”, Süleyman Demirel Üniversitesi, Fen Bilimleri Enstitüsü Dergisi, 11-1, 38-47.

Yavuz, Yıldırım (1988). "Batılaşma Döneminde Osmanlı Sağlık Kuruluşları", ODTÜ Mimarlık Fakültesi Dergisi 8:2 123-142.

Yazıc1 Metin, Nurcan (2019a). "Osmanlı'da Gurebâ Hastaneleri: Canik/ Samsun Gurebâ Hastanesi'nin İnşa Süreci ve Kitabesi”, TUBA-KED, Türkiye Bilimler Akademisi Kültür Envanteri Dergisi 19: 47-54.

Yazıc1 Metin, Nurcan (2019b). Tanzimat'tan Cumhuriyet'e Hükümet Konaklarının İşa Süreci ve Mimarisi-Devlet Kapısı. İstanbul: Kitabevi Yayınları.

Yazıcı Metin, Nurcan (2020a). "Salgının Mimarisi: Osmanlı' da Frengi ve Gurebâ Hastaneleri (Kastamonu Vilayeti Örneği)”, MSGSU Sosyal Bilimler Dergisi, 2 (22): s. 252-270.

Yazıcı Metin, Nurcan (2020b). “Osmanlı'nın Son Döneminde Bir Kasaba Hastanesi: İnşa Süreci ve Mimarisiyle Dedeağaç Gurebâ Hastanesi”, Ege Üniversitesi Sanat Tarihi Dergisi, 29/2, Ekim, s. 945-961.

Yıldırım, Nuran (2019). "Bezmialem Vakıf Gureba Hastanesi", Vakıf Kuran Kadınlar. Bildiriler. Haz. F. Başar, Ankara: Vakıflar Genel Müdürlüğü Yayınlar1, s. 201-241.

\section{BOA. / Cumhurbaşkanlığı/ Başkanlık Osmanlı Arşivi Belgeler:}

BOA., BEO., 2427/181978, 1 Şaban 1322, 11 Ekim 1904.

BOA., BEO., 2436/182664, 15 Şaban 1322, 25 Ekim 1904.

BOA., DH.ID., 47/32, 14 Zilhicce 1329, 6 Aralık 1911.

BOA., DH.MKT., 816/54, 30 Teşrin-i evvel 319, 12 Kasım 1903.

BOA., DH.MKT., 816/54, 2 Zilkade 1321, 19 Ocak 1904.

BOA.,DH.MKT., 997/29, 12 Safer 1323, 18 Nisan 1905.

BOA., DH.MKT., 947/69, 12 Safer 1323, 18 Nisan 1905.

BOA. DH.MKT., 816/54, 30 Teşrin-i evvel 319, 12 Kasım 1903.

BOA., DH.MUİ, 4/6, 20 Şaban 1327, 6 Eylül 1909.

BOA., FTG., No: 1703. 
BOA., İ.DFE., 15/41, 23 Teşrinisani 1320, 6 Aralık 1904.

BOA., İ.HUS., 122/35, 14 Şaban 1322, 24 Ekim 1904.

BOA., ŞD, 1758/3, 8 Cemaziyelahir 1322, 20 Ağustos 1904.

BOA., ŞD., 1759/7, 22 Cemazeyilevvel 1323, 25 Temmuz 1905.

BOA., Y.A.RES., 132/87, 20 Recep 1323, 20 Eylül 1905.

BOA., Y.A.RES., 132/87, 22 Cemaziyellevvel 1323, 25 Temmuz 1905.

BOA., Y.PRK.BŞK., 65/9, 8 Cemaziyelevvel 1319, 23 Ağustos 1901. 